\title{
Informal Discussion
}

An informal discussion on "Light Planes,". to be opened by Mr. W. E. Gray, will take place in the Society's Library at 7.0 p.m. on Friday, April 8th.

The discussion has been arranged by the Students' Section, but members in any grade will be welcome.

\section{Students' Section}

On Saturday, February 26 th a party of about 60 students, including a group from the City and Guild Engineering College, visited the De Havilland Aircraft Co. at Stag Lane Aerodrome. They were shown all over the workshops and took great interest in the mass production of "Moths" and in "Hercules V." which was nearing completion. Afterwards a number had flights in "Moth" machines.

On Friday, March I8th, a very interesting lecture on the "Recent Developments in the Construction of Rigid Airships " was given by Mr. W. T. Sandford, of the Airship Guarantee Company, with Major Scott, A.F.C., C.B.E., in the chair. Mr. Sandford gave a clear account of problems met with in the construction of rigids and showed how they might be overcome. Seventeen students were present and about twelve took part in the discussion.

\section{Library}

The following books have been recently received and placed in the Library :Reprints of two papers by E. H. Hankin, "The Evolution of Flying Animals" and "Soaring Flight"; "Kolben fur Kraftfahrzeugmotoren: Grauguss, Aluminium, Elektron," by E. Mahle; "Der Luftschiffbau Schutte-Lanz I9o9I925," by J. Schütte; R. \& M. No. IO4I, "Accidents to Aeroplanes Involving Flutter of the Wings"; R. \& M. No. I045, "On the Equivalence between the Dynamical System of a Multi-Crank Flywheel System and a certain Electrical Circuit...," by E. B. Moullin; “Diesel Engines," by A. H. Goldingham; R. \& M. No. I049, " Direct Measurement of the Angle of Flight Path, ...," by E. T. Jones and H. L. Stevens; R. \& M. No. 105I, "Second Report on FullScales Experience with the Slot and Aileron Control, ...,"' by R. L. Stevens; "Fogs and Clouds," by W. J. Humphries; R. \& M. No. Io34, "The Efficiency of an Airscrew," by H. Glauert; "Turbomotore a Compressore a Nafta," by Gen. A. Guidoni; Report on Civil Aviation, Department of National Defence, Ottawa; "The Study of War," by Sir George Aston; "Mechanics Applied to Engineering," Volumes I. and II., by J. Goodman; and "Land, Sea and Air," by Admiral Mark Kerr.

\section{Forthcoming Arrangements}

Thursday, April 7th, 5.15 p.m.-At the Royal Society of Arts, 18, John Street, Adelphi, W.C.2, "Parachutes," by Flight Lieut. F. O. Soden, D.F.C.

Thursday, April 28th, at 6.30 p.m.-At the Royal Society of Arts, 18, John Street, Adelphi, W.C.2, "Seaplane Development," by Major R. E. Penny, A.F.R.Ae.S.

\section{J. Laurence Pritchard, Secretary.}

\section{$O B I T U A R Y$}

Flight Lieutenant W. A. Meggitt, Associate.

It is with great regret we have to record the death, through the crashing of his aeroplane at Croydon on January 28th last, of Flight Lieutenant W. G. Meggitt, an Associate of the Society. Flight Lieutenant. W. G. Meggitt joined the Society on January IIth, I927, and was one of its most enthusiastic members.

The Cruncil wish to express their deep sympathy with Mrs. Meggitt on the loss of her husband. 